\title{
Optimasi Penempatan Distributed Generation (DG) dan Kapasitor pada Sistem Distribusi Radial Menggunakan Metode Genetic Algorithm (GA) (Studi Kasus pada Penyulang Watu Ulo Jember)

\author{
(Optimazing the Placement Of Distributed Generation (DG) and Capacitor In Distribution Radial \\ System With Genetic Algorithm (GA) Method (Case Study At Watu Ulo feeder Jember))
}

\author{
Dony Kurniyawan Tabarok, Azmi Saleh, Bambang Sri Kaloko \\ Jurusan Teknik Elektro, Fakultas Teknik, Universitas Jember (UNEJ) \\ Jln. Kalimantan 37, Jember 68121 \\ E-mail: dony_kurniyawan@yahoo.com
}

\begin{abstract}
Abstrak
Dalam memperbaiki penyuplaian sistem tenaga listrik dapat dilakukan dengan mengoptimasi penempatan dari distributed generation (DG) dan kapasitor serta ukurannya pada suatu sistem distribusi tenaga listrik. Dalam mengoptimasi penempatan serta ukurannya digunakan suatu metode yakni genetic algorithm (GA). GA adalah algoritma yang berusaha menerapkan pemahaman mengenai evolusi alamiah pada tugas-tugas pemecahan masalah (problem solving). Pada penelitian ini didapat penempatan dan ukuran yang optimal dari DG dan kapasitor yakni pada bus 3, 49, 51, 64 dan 70 dengan ukuran DG sebesar 4, 46, 41, 50 dan $22 \mathrm{~kW}$ serta ukuran kapasitor sebesar 23, 15, 54, 8 dan $11 \mathrm{kVAr}$. Didapat nilai total rugi-rugi daya sebesar $600.9546 \mathrm{~kW}$ pada daya aktif dan daya reaktif sebesar $605.4042 \mathrm{kVAr}$. Sedangkan sebelum penempatan DG dan kapasitor terdapat nilai total rugi-rugi daya sebesar $657.3084 \mathrm{~kW}$ pada daya aktif dan daya reaktif sebesar $663.7226 \mathrm{kVAr}$. Hal ini membuktikan dengan adanya penempatan DG dan kapasitor dapat memperbaiki daya aktif dan daya reaktifnya. Serta terdapat perbaikan profil tegangan disetiap busnya setelah adanya penempatan dari DG dan kapasitor dibandingkan sebelum adanya penempatan dari DG dan kapasitor, dimana pada bus 60 mengalami perbaikan profil tegangan dari 0.8454 Volt menjadi 0.8523 Volt.
\end{abstract}

Kata Kunci: Distributed Generation (DG), Genetic Algorithm (GA), Kapasitor

\section{Abstract}

In the repair of supplying the electric power system can be done by optimizing the placement of distributed generation (DG) and capacitors as well as size in a power distribution system.. In order for a placement optimization and size to use a method that is genetic algorithm (GA). GA is an algorithm that seeks to apply an understanding of the natural evolution of the tasks of problem solving (problem solving). In this study, obtained placement and optimal size of the DG and the capacitor that is on bus 3, 49, 51, 64 and 70 with the size of the DG of 4, 46, 41, 50 and $22 \mathrm{~kW}$ as well as capacitor size by $23,15,54,8$ and $11 \mathrm{kVAr}$. Obtained value total power loss amounted to $600.9546 \mathrm{~kW}$ active power and reactive power at $605.4042 \mathrm{kVAr}$. Whereas prior to the placement of DG and capacitors contained a total value of power losses amounted to $657.3084 \mathrm{~kW}$ active power and reactive power at $663.7226 \mathrm{kVAr}$. This is proved by the DG and the capacitor placement can improve active power and reactive power. And improvements in every bus voltage profile after the placement of the DG and the capacitor than prior to the placement of the DG and the capacitor, where the bus 60 has improved voltage profile becomes 0.8523 Volt from 0.8454 Volt.

Keywords: Distributed Generation (DG), Genetic Algorithm (GA), Capacitor

\section{PENDAHULUAN}

Energi listrik merupakan suatu bentuk energi yang memiliki peran sangat vital dalam aktivitas keseharian manusia. Setiap tahun terjadi peningkatan kebutuhan energi yang signifikan dan menuntut pihak penyedia tenaga listrik untuk memberikan supply tenaga yang cukup dan berkualitas. Sistem distribusi merupakan bagian dari sistem tenaga listrik yang berfungsi untuk menyalurkan dan mendistribusikan daya listrik yang berasal dari pusat pembangkit ke konsumen. Mengingat kebutuhan masyarakat akan energi listrik terus meningkat seiring dengan meningkatnya gaya hidup dan peralatan yang digunakan, pada kondisi ini mengharuskan akan ketersediaan energi listrik yang efisien dan berkualitas [1].
DG dinilai sebagai suatu solusi yang tepat untuk mengatasi kekurangan pasokan energi listrik maupun mengatasi problematika sistem distribusi listrik seperti rugirugi daya listrik, keseimbangan sistem distribusi listrik, dan juga mengatasi beban kritis yang mengalami drop tegangan [2]. Biasanya dalam memperbaiki rugi-rugi daya dan tegangan hanya menggunakan pengaruh dari daya aktif tanpa menganalisis pengaruh dari adanya daya reaktif. Maka, pada penelitian ini akan dibahas mengenai pengaruh dari adanya daya reaktif dengan menempatkan kapasitor pada sistem distribusi radial. Sehingga dilakukan penelitian penempatan DG dan kapasitor secara bersama pada jaringan distribusi radial. Pada penelitian ini, digunakan penyulang Watu Ulo Jember karena pada penyulang ini mempunyai 
nilai rugi-rugi daya listrik dan juga mempunyai drop tegangan.

Dalam hal ini, untuk mengahasilkan nilai rugi-rugi daya dan tegangan yang optimal akan digunakan GA sebagai metode optimasi. GA adalah algoritma yang berusaha menerapkan pemahaman mengenai evolusi alamiah pada tugas-tugas pemecahan masalah (problem solving). Pendekatan yang diambil oleh GA ini adalah dengan menggabungkan secara acak sebagai pilihan solusi terbaik didalam suatu kumpulan untuk mendapatkan generasi solusi terbaik. GA (Genetic Algorithm) digunakan untuk mendapatkan solusi yang tepat untuk masalah optimasi dari satu atau multi variable [3].

\section{TINJAUAN PUSTAKA}

\section{Distributed Generation (DG)}

Secara mendasar, DG menghasilkan energi listrik dari beberapa sumber energi yang berkapasitas kecil dan dihubungkan langsung pada jaringan distribusi. Distributed generation adalah pembangkit listrik yang melayani konsumen di tempat (on-site), atau untuk mendukung jaringan distribusi, dan terhubung ke jaringan pada level tegangan distribusi. Teknologinya secara umum terdiri dari mesin, turbin kecil (termasuk turbin mikro), fuel cell dan photovoltaic serta teknologi pembangkitan energi listrik berskala kecil yang menghasilkan daya listrik di suatu tempat yang lebih dekat dengan konsumen dibandingkan dengan pembangkit listrik pusat.

\section{Kapasitor Bank}

Kapasitor Bank merupakan peralatan listrik yang mempunyai sifat kapasitif yang terdiri sekumpulan beberapa kapasitor yang disambung secara paralel untuk mendapatkan kapasitas kapasitif tertentu. Besaran parameter yang sering dipakai adalah KVAR (Kilovolt ampere reaktif) meskipun pada kapasitor sendiri tercantum besaran kapasitansi yaitu Farad atau microfarad. Kapasitas kapasitor dari ukuran 5 KVar sampai 60 Kvar. Dari tegangan kerja $230 \mathrm{~V}$ sampai 525 Volt. Kapasitor ini mempunyai sifat listrik yang kapasitif (leading). Sehingga mempunyai sifat mengurangi atau menghilangkan terhadap sifat induktif (leaging). Fungsi utama dari kapasitor bank yaitu sebagai penyeimbang beban induktif, Seperti yang kita ketahui beban listrik terdiri dari beban reaktif (R), induktif (L) dan capasitif (C).

\section{Genetic Algorithm (GA)}

GA adalah algoritma yang berusaha menerapkan pemahaman mengenai evolusi alamiah pada tugas-tugas pemecahan masalah (problem solving). Pendekatan yang diambil oleh GA ini adalah dengan menggabungkan secara acak sebagai pilihan solusi terbaik didalam suatu kumpulan untuk mendapatkan generasi solusi terbaik berikutnya yaitu pada suatu kondisi yang memaksimalkan kecocokannya atau lazim disebut fitness. Generasi ini akan mempresentasikan pernaikan-perbaikan pada populasi awalnya. Dengan melakukan proses ini secara berulang, GA ini diharapkan dapat mensimulasikan proses evolusioner. Untuk menggunakan GA, solusi permasalahan direpresentasikan sebagai kromosom. Berikut adalah tiga aspek penting untuk penggunaan GA :

a. Definisi fungsi fitness. b. Definisi dan implementasi representasi genetic.

c. Definisi dan implementasi operasi genetic.

\section{METODE PENELITIAN}

Sebuah Algoritma Genetika (GA) adalah algoritma pencarian yang didasarkan pada hipotesis seleksi alam. GA berdasarkan proses pencarian evolusi yang dimulai dengan set populasi yang sangat besar sebagai calon awal solusi. Solusi ini mengalami seleksi didasarkan pada fitness dan operator genetik lain yang berguna dalam pencarian solusi. Masing-masing kandidat solusi dikenal sebagai kromosom, dan himpunan semua kromosom dibuat dari sebelumnya ditetapkan melalui apa yang disebut operator genetik. Dalam setiap generasi, kromosom kebugaran masingmasing didefinisikan sedemikian rupa sehingga kromosom dengan fitness tertinggi mewakili titik optimal dalam ruang pencarian.

\section{Baca Data DG dan Kapasitor}

Untuk proses awal sebelum dilakukan pemilihan atau optimasi penempatan dan kapasitas DG dan kapasitor, hal yang dilakukan adalah mengetahui berapa banyak individu yang akan dibangkitkan dan juga berapa variabel yang akan dibangkitkan sebagai pembanding dari variabel lainnya. Dimana variabel yang dibangkitkan itu merupakan data penempatan DG dan kapasitor itu sendiri.

\section{Bangkitkan Populasi Awal}

Dalam membangkitkan populasi awal ini dilakukan secara random, jadi untuk penempatan DG dan kapasitor dilakukan secara acak tanpa harus melihat pada bus mana yang harus ditempatkan. Desain individu ini tidak lain adalah sekumpulan individu yang akan diproses bersama dalam satu siklus proses evolusi, hal ini dilakukan dengan menggunakan pembangkitan secara acak seperti random, yang dimana terlebih dahulu menentukan parameter popsize sebagai variabel individu yang akan dibangkitkan, kemudian stringlength sebagai jumlah gen atau perwakilan dari jumlah bus yang akan diproses. Untuk pembangkitan penempatan dan kapasitas pada setiap variabel individu dilakukan dengan batasan 5 penempatan DG dan kapasitor pada posisi bus yang sama, dimana pada setiap penempatannya diberikan kapasitas dengan hasil optimasi kapasitas itu sendiri. Dalam populasi yang dibangkitkan menggunakan bilangan biner dimana setiap nilai 1 (satu) merupakan terdapat penempatan DG dan kapasitor sedangkan untuk nilai 0 (nol) dapat diartikan tidak terdapat penempatan DG dan kapasitor.

\section{Fitness Objektif Optimal}

Fitness merupakan nilai yang menyatakan baik tidaknya suatu solusi (individu). Nilai fitness ini dijadikan acuan dalam mencapai nilai optimal pada metode GA, sedangkan GA itu sendiri bertujuan untuk mencari nilai individu dari fitness yang terendah. Jadi penempatan DG dan kapasitor ditentukan dengan pembangkitan populasi secara acak dan diproses pada fitness guna untuk mencari individu dengan kreteria fitness terendah. Untuk pemilihan fitness yang optimal yaitu berdasarkan populasi yang dibangkitkan. Dimana dengan populasi tersebut fitness dapat memilih variabel yang dianggap paling optimal. 


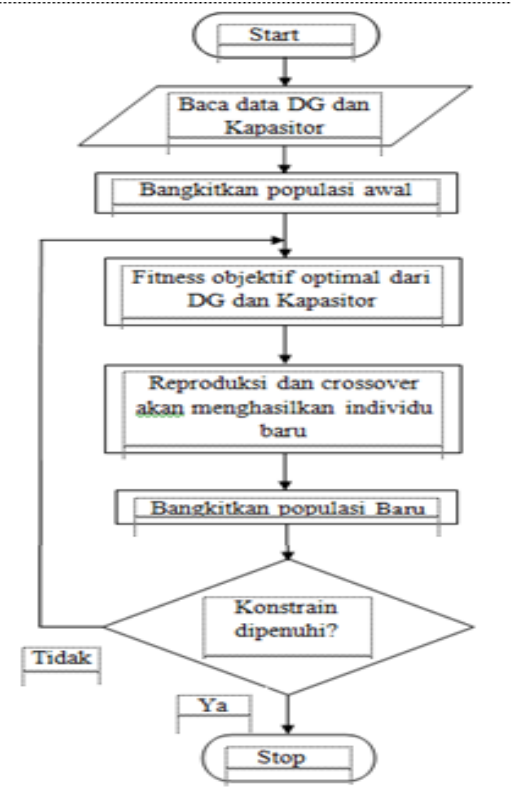

Gambar 1. Diagram Flowchart Penelitian

\section{Membuat Individu Baru}

Pada proses optimasi menggunakan GA terkadang terdapat pembuatan individu baru yang harus dilakukan, hal ini terjadi karena pada populasi awal tedapat nilai fitness yang kurang optimal sehingga perlu adanya pembangkitan individu baru dengan tujuan untuk mencari hasil yang optimal dari populasi awal yang telah dibangkitkan sebelumnya. Proses ini terjadi dengan cara reproduksi dan juga proses crossover.

\section{Bangkitkan Populasi Baru}

Untuk membangkitkan populasi baru, terlebih dahulu harus mengetahui kondisi individunya karena pada populasi terdapat beberapa jumlah individu. Dan dari individu tersebut dapat dibangkitkan populasi baru dengan secara random sehingga dapat langsung diproses kedalam fitness untuk mengetahui hasil yang optimal.

\section{HASIL DAN PEMBAHASAN}

Dilakukan beberapa analisis pada penelitian ini yakni analisis data sebelum penempatan DG dan kapasitor serta dibandingkan dengan hasil simulasi ETAP, optimasi penempatan serta ukuran DG dan kapasitor, perbandingan hasil data sebelum dan sesudah penempatan DG dan kapasitor, perbandingan hasil data penempatan DG dan kapasitor secara acak dengan yang optimal serta perbandingan hasil data penempatan DG dan kapasitor. Data yang akan dijadikan data pengujian terdiri atas rugirugi daya aktif dan reaktif serta profil tegangan yang dilakukan dengan menggunakan metode aliran daya Backward Forward Sweep yang kemudian diuji dan dibandingkan dengan hasil dari simulasi ETAP.

Analisis Data Sebelum Penempatan DG dan Kapasitor serta Perbandingan dengan Simulasi ETAP

Dari hasil aliran daya didapatkan total losses pada daya aktif sebesar $657.3084 \mathrm{~kW}$ sedangkan untuk total losses pada daya reaktif didapatkan sebesar $663.7226 \mathrm{kVAr}$. Dari hasil losses daya aktif dan reaktif, didapatkan bahwa nilai rugi daya terbesar terletak pada saluran dari bus 1 ke bus 21 dengan rugi daya aktif sebesar $309.1736 \mathrm{~kW}$ dan rugi daya reaktif sebesar $282.7136 \mathrm{kVAr}$. Nilai rugi daya terbesar pada saluran dari bus 1 ke bus 21 ini disebabkan memiliki jarak yang jauh, pembebanannya yang besar serta disebabkan oleh impedansi dan reaktansi terbesar terletak pada bus 20 terutama pada bus 1 ke bus 21 yakni dengan resistansi sebesar 0.9781 pu dan reaktansi sebesar 0.8944 pu. Sedangkan untuk nilai rugi daya terkecil terletak pada saluran bus 13 ke bus 14 dengan rugi daya aktif sebesar $0.0000 \mathrm{~kW}$ dan rugi daya reaktif sebesar $0.0001 \mathrm{kVA}$ dengan nilai resistansi sebesar 0.0369 pu dan reaktansi sebesar $0.2903 \mathrm{pu}$.

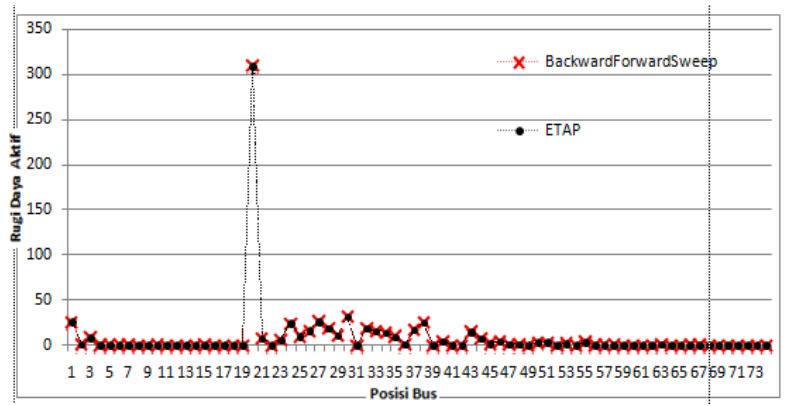

Gambar 2. Perbandingan Rugi Daya Aktif

Dari hasil perbandingan diatas masih terdapat selisih antara perhitungan Matlab dengan simulasi ETAP, akan tetapi selisih yang didapatkan tidak terlalu jauh atau signifikan. Selisih hasil yang didapatkan tidak melebihi dari $1 \mathrm{~kW}$ dan hal tersebut masih dapat dikategorikan baik. Pada perhitungan Matlab pada saluran bus 1 ke bus 2 didapatkan rugi-rugi daya sebesar $26.0023 \mathrm{~kW}$ sedangkan pada simulasi ETAP didapatkan rugi-rugi daya sebesar 26.0844, hal ini mempunyai selisih sebesar 0.0821. Begitu juga pada saluran bus 41 ke bus 44 didapatkan rugi-rugi daya sebesar $15.3006 \mathrm{~kW}$ sedangkan pada simulasi ETAP didapatkan rugi-rugi daya sebesar $15.3348 \mathrm{~kW}$, hal ini mempunyai selisih sebesar 0.0342. Sedangkan untuk daya reaktif pada perhitungan Matlab pada saluran bus 1 ke bus 2 didapatkan rugi-rugi daya sebesar $23.8191 \mathrm{kVAr}$ sedangkan pada simulasi ETAP didapatkan rugi-rugi daya sebesar 23.8943 $\mathrm{kVAr}$, hal ini mempunyai selisih sebesar $0.0752 \mathrm{kVAr}$. Begitu juga pada saluran bus 41 ke bus 44 didapatkan rugirugi daya sebesar $1.9533 \mathrm{kVAr}$ sedangkan pada simulasi ETAP didapatkan rugi-rugi daya sebesar $1.9576 \mathrm{kVAr}$, hal ini mempunyai selisih sebesar 0.0043 .

Dari hasil profil tegangan, dengan bertambahnya jumlah bus maka profil tegangan pun akan semakin menurun pula dari nilai 1 pu sampai menuju pada bus 75 yang mencapai nilai tegangan sebesar 0.8432 pu. Drop tegangan terbesar terjadi pada bus 21 yakni sebesar $0.9150 \mathrm{pu}$ dimana tegangan sebelumnya pada bus 20 didapatkan sebesar 0.9702 pu. Dari hasil perbandingan masih terdapat selisih antara perhitungan Matlab dengan simulasi ETAP, akan tetapi selisih yang didapatkan tidak terlalu jauh atau signifikan. Selisih hasil yang didapatkan tidak melebihi dari $1 \mathrm{pu}$ dan hal tersebut masih dapat dikategorikan baik. Pada perhitungan Matlab pada saluran bus 17 ke bus 18 didapatkan profil tegangan sebesar 0.9706 pu sedangkan pada simulasi ETAP didapatkan profil tegangan sebesar 
0.9701 pu, hal ini mempunyai selisih sebesar 0.0005 . Begitu juga pada saluran bus 41 ke bus 44 didapatkan profil tegangan sebesar 0.8634 pu sedangkan pada simulasi ETAP didapatkan profil tegangan sebesar $0.8627 \mathrm{pu}$, hal ini mempunyai selisih sebesar 0.0007 .

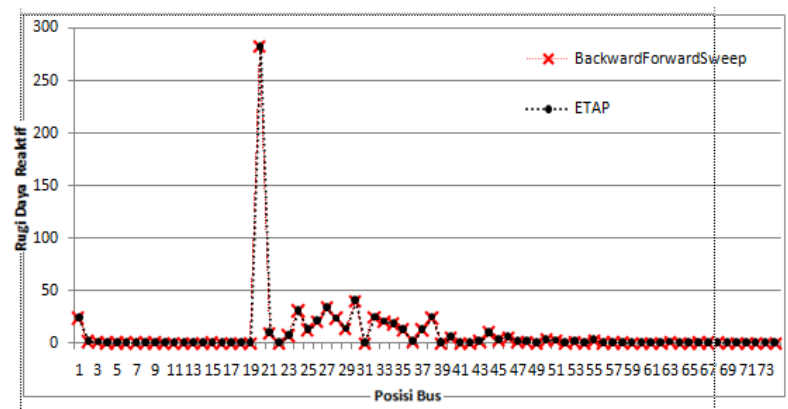

Gambar 3. Perbandingan Rugi Daya Reaktif

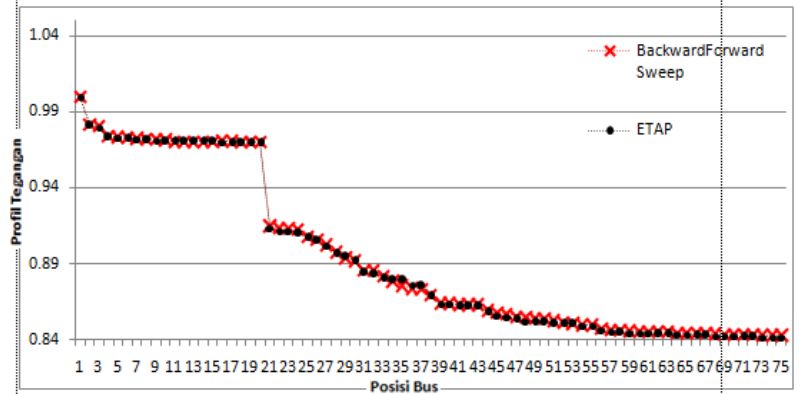

Gambar 4. Perbandingan Profil Tegangan

Optimasi Penempatan serta Ukuran DG dan Kapasitor

Pada sistem 75 bus dalam penelitian ini untuk langkah proses optimasinya menggunakan proses GA (Algoritma Genetic) pada Matlab, dengan tujuan untuk memperoleh posisi dan ukuran yang tepat pada DG dan kapasitor untuk mengurangi rugi-rugi daya dan memperbaiki profil tegangan. Dalam percobaan sistem 75 bus ini dibatasi dengan 5 penempatan dari DG dan kapasitor. Penentuan tempat dan kapasitas dibangkitkan secara acak oleh GA, dimana kapasitas maksimal yang digunakan DG sebesar 50 KW dan kapasitas maksimal kapasitor sebesar 100 Kvar. Dalam proses GA untuk penempatan serta ukuran dari DG dan kapasitor menggunakan secara acak atau random.

Dari hasil optimasi diatas dapat diketahui posisi atau penempatan dari DG dan kapasitor terdapat pada bus 3 dengan ukuran $4 \mathrm{KW}$ dan $23 \mathrm{Kvar}$, bus 49 dengan ukuran $46 \mathrm{KW}$ dn $15 \mathrm{Kvar}$, bus 51 dengan ukuran $41 \mathrm{KW}$ dan 54 Kvar, bus 64 dengan ukuran $50 \mathrm{KW}$ dan 8 Kvar serta pada bus 70 dengan ukuran $22 \mathrm{KW}$ dan $11 \mathrm{Kvar}$.

Dapat kita lihat akibat adanya penempatan DG dan kapasitor ini dianggap mampu memperbaiki nilai total rugirugi daya baik dari daya aktif maupun daya reaktif dibandingkan pada saat sebelum penempatan dari DG dan kapasitor. Adapun nilai rugi-rugi daya aktif sebelum penempatan dari DG dan kapasitor adalah sebesar 657.3084 $\mathrm{kW}$ dan nilai rugi-rugi daya reaktif adalah sebesar 663.7226 kVAr.

Namun setelah adanya optimasi penempatan dan ukuran dari DG dan kapasitor, rugi-rugi daya sebesar 600.9546 $\mathrm{kW}$ pada daya aktif serta $605.4042 \mathrm{kVAr}$ pada daya reaktif, hal ini dapat disimpulkan bahwa optimasi penempatan DG dan kapasitor mampu menurunkan nilai total rugi-rugi daya sebesar $56.3538 \mathrm{~kW}$ pada daya aktif serta menurunkan nilai total rugi-rugi daya reaktif sebesar $58.3184 \mathrm{kVAr}$. Perlu diketahui bahwa setiap nilai total rugi-rugi daya tersebut dipengaruhi oleh penempatan serta ukuran dari DG dan kapasitor yang optimal. Misalnya pada bus 1 ke bus 21 sebelum penempatan DG dan kapasitor nilai rugi-rugi daya aktif sebesar $309.1736 \mathrm{~kW}$, setelah adanya optimasi penempatan DG dan kapasitor menurun menjadi 283.4700 $\mathrm{kW}$ dan pada bus 49 ke bus 51 mengalami penurunan dari $3.4554 \mathrm{~kW}$ menjadi $3.1769 \mathrm{~kW}$. Dari data tersebut terdapat perbedaan juga dimana pada bus 26 ke bus 27 mengalami penurunan nilai rugi-rugi daya aktif dari $16.3388 \mathrm{~kW}$ menjadi $14.8160 \mathrm{~kW}$.

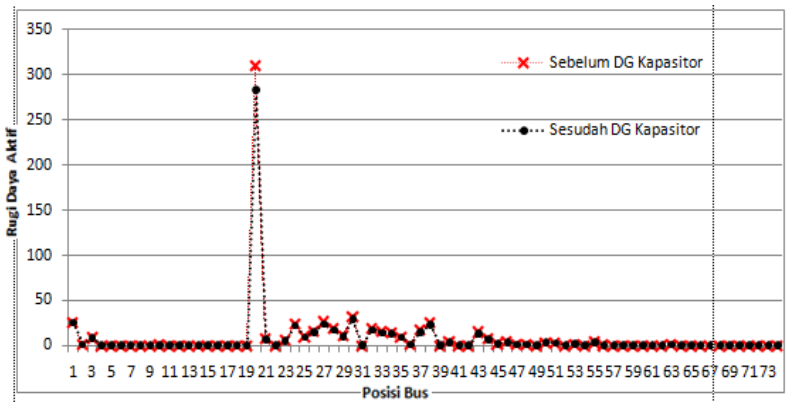

Gambar 5. Perbandingan Rugi Daya Aktif

Untuk daya reaktif pada bus 1 ke bus 21 sebelum penempatan DG dan kapasitor sebesar $282.7163 \mathrm{kVAr}$, kemudian setelah adanya optimasi penempatan DG dan kapasitor menurun menjadi $259.2123 \mathrm{kVAr}$ dan pada bus 49 ke bus 51 mengalami penurunan dari $2.9814 \mathrm{kVAr}$ menjadi $2.7411 \mathrm{kVAr}$. Jika disimpulkan ini tergolong baik karena dengan adanya penambahan DG dan kapasitor mampu memperbaiki nilai rugi-rugi daya aktif dan daya reaktif yang ada.

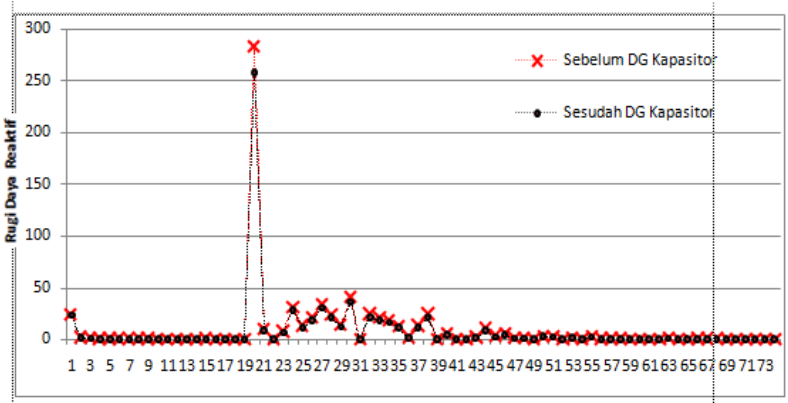

Gambar 6. Perbandingan Rugi Daya Reaktif

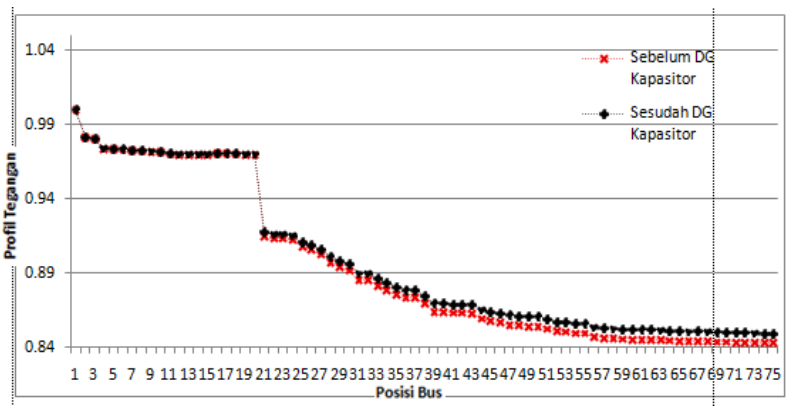

Gambar 7. Perbandingan Profil Tegangan 
Dapat diliat pada bus 21 dimana nilai tegangan sebelum adanya penempatan dari DG dan kapasitor sebesar 0.9150 pu, kemudian setelah adanya penempatan dan ukuran dari DG dan kapasitor berubah menjadi 0.9178 pu. Misal pada bus 60 juga mengalami perbaikan profil tegangan dari 0.8454 pu menjadi 0.8523 pu.

\section{Perbandingan Hasil Data Penempatan DG dan} Kapasitor Secara Acak dengan yang Optimal

Pada analisis percobaan pada sistem 75 bus dengan penambahan DG dan kapasitor secara acak, yang ditempatkan pada bus 5, 23, 38, 58 dan 73 dengan tujuan untuk membandingkan hasil dengan penempatan yang sudah dioptimalkan dengan metode GA. Didapatkan total rugi daya aktif sebesar $610.5446 \mathrm{~kW}$ dan rugi daya reaktif sebesar 616.067 kVAr. Sedangkan hasil percobaan menggunakan GA didapatkan total rugi daya aktif 600.9546 $\mathrm{kW}$ dan rugi daya reaktif sebesar $605.4042 \mathrm{kVAr}$. Pada penempatan secara acak di saluran bus 1 ke 21 dihasilkan $284.6849 \mathrm{~kW}$ dan 260.3233 kVAr dan percobaan yang menggunakan GA dihasilkan $283.4700 \mathrm{~kW}$ dan 259.2123 kVAr.

Didapatkan profil tegangan dengan penempatan secara acak pada bus 75 sebesar 0.8487 pu sedangkan dengan menggunakan percobaan metode GA dihasilkan profil tegangan sebesar $0.8497 \mathrm{pu}$. Dari hasil tersebut dapat diartikan bahwa hasil optimasi menggunakan metode GA adalah hasil yang paling optimal karena nilai total rugi-rugi daya dan rugi-rugi salurannya lebih kecil.

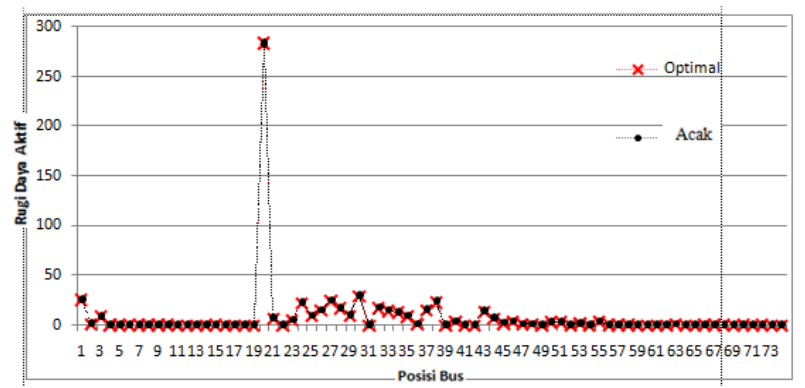

Gambar 8. Perbandingan Rugi Daya Aktif

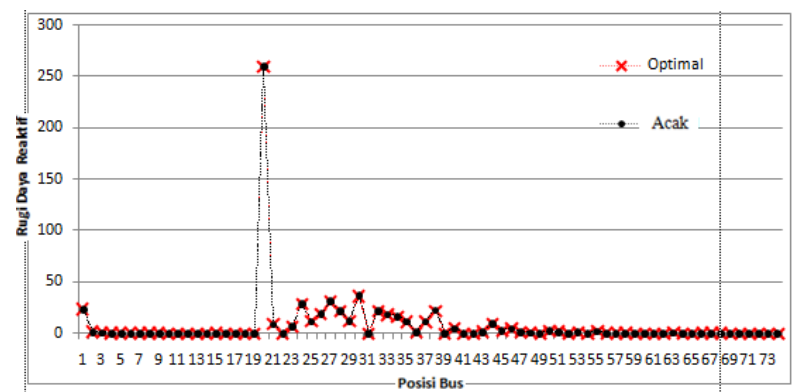

Gambar 9. Perbandingan Rugi Daya Reaktif

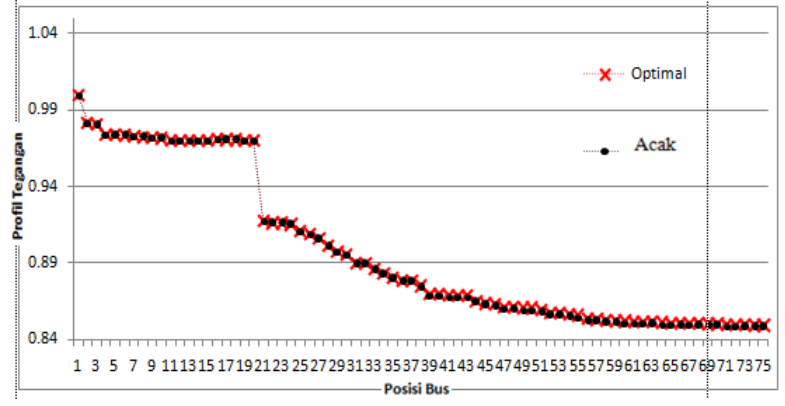

Gambar 10. Perbandingan Profil Tegangan

Perbandingan Hasil Data Penempatan DG dan Kapasitor

Pada analisa kali ini dibandingkan hasil data penempatan dari DG dan kapasitor yang ditempatkan secara bersama dengan penempatan DG dan kapasitor yang ditempatkan secara terpisah serta dengan penempatan dan ukuran yang sudah menggunakan metode optimasi GA. Dihasilkan total rugi daya aktif dengan menambahkan DG sebesar $611.6429 \mathrm{~kW}$, dengan kapasitor sebesar 646.5047 $\mathrm{kW}$ serta dengan menambahkan DG dan kapasitor secara bersama sebesar $600.9546 \mathrm{~kW}$. Sedangkan total rugi daya reaktif dengan DG dihasilkan sebesar 616.5044 kVAr, dengan kapasitor sebesar $652.5903 \quad \mathrm{kVAr}$ serta menempatkan DG dan kapasitor sebesar $605.4042 \mathrm{kVAr}$. Untuk hasil profil tegangan dihasilkan dengan menempatkan DG pada bus 72 sebesar $0.8456 \mathrm{pu}$, dengan kapasitor dihasilkan 0.8483 pu serta dengan menggabungkan DG dan kapasitor dihasilkan sebesar 0.8502 pu.

Begitu juga pada bus 21 dengan menggabungkan DG dan kapasitor menghasilkan profil tegangan yang lebih baik yakni $0.9178 \mathrm{pu}$. Dari hasil tersebut dapat diartikan bahwa dengan menggabungkan DG dan kapasitor lebih optimal karena nilai total rugi-rugi daya dan rugi-rugi saluran lebih kecil, selain itu profil tegangannya juga lebih baik.

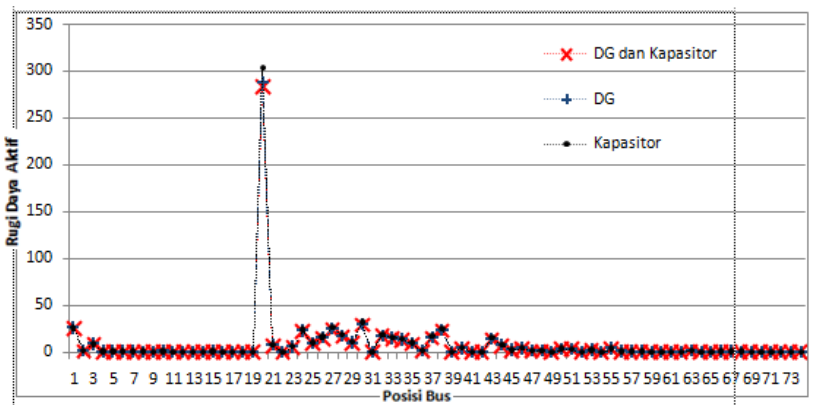

Gambar 11. Perbandingan Rugi Daya Aktif

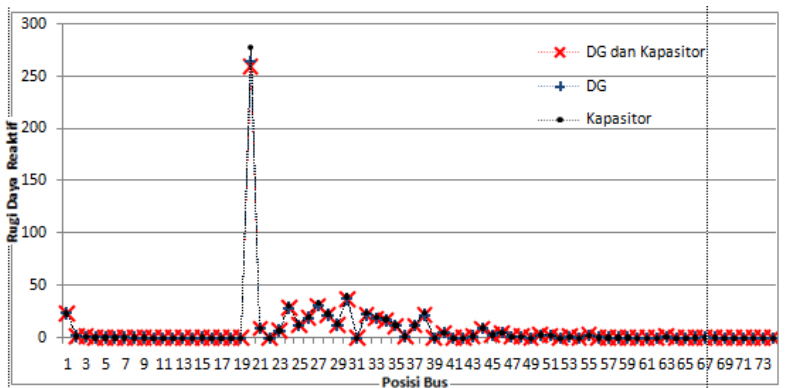


Gambar 12. Perbandingan Rugi Daya Reaktif

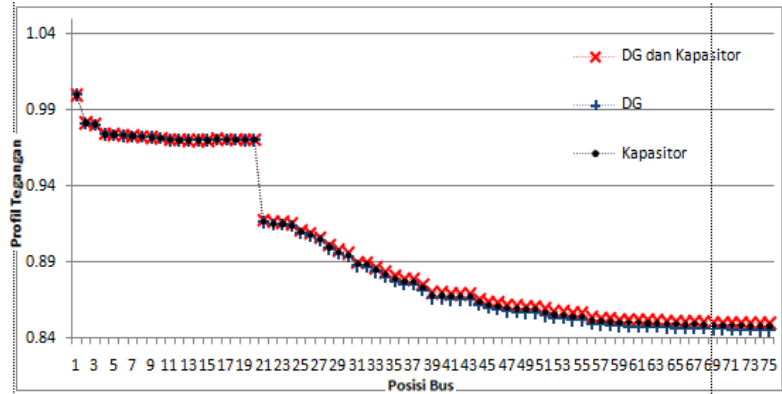

Gambar 13. Perbandingan Profil Tegangan

\section{KESIMPULAN}

Kesimpulan dari pengujian dan analisis data yang telah dilakukan adalah :

1. Dengan menggunakan optimasi Genentic Algorithm (GA) didapat penempatan dan ukuran yang optimal dari DG dan kapasitor yakni pada bus 3, 49, 51, 64 dan 70 dengan ukuran DG sebesar 4, 46, 41, 50 dan $22 \mathrm{~kW}$ serta ukuran kapasitor sebesar 23, 15, 54, 8 dan $11 \mathrm{kVAr}$.

2. Setelah dilakukan optimasi menggunakan GA (Genetic Algoritm) didapat nilai total rugi-rugi daya sebesar $600.9546 \mathrm{~kW}$ pada daya aktif dan daya reaktif sebesar 605.4042 kVAr dengan 5 penempatan DG dan kapasitor pada bus. Sedangkan sebelum penempatan DG dan kapasitor terdapat nilai total rugi-rugi daya sebesar $657.3084 \mathrm{~kW}$ pada daya aktif dan daya reaktif sebesar 663.7226 kVAr. Hal ini membuktikan dengan adanya penempatan DG dan kapasitor dapat memperbaiki daya aktif dan daya reaktifnya.

3. Terdapat perbaikan profil tegangan disetiap busnya setelah adanya penempatan dari DG dan kapasitor dibandingkan sebelum adanya penempatan dari DG dan kapasitor. Pada bus 60 mengalami perbaikan profil tegangan dari 0.8454 p.u menjadi 0.8523 p.u.

\section{SARAN}

Beberapa saran yang dapat dipertimbangkan untuk pengembangan penelitian selanjutnya adalah:

1. Aplikasi penempatan DG (Distributed Generation) dan penentuan kapasitas DG (Distributed Generation) dapat di optimalkan pada sistem jaringan lain.

2. Dengan penambahan jumlah variabel dapat mengoptimalkan nilai dan meningkatkan ketelitian GA (Genetic Algoritm).

\section{DAFTAR PUSTAKA}

[1] Muntowifah, Siti. 2014. Optimasi Penempatan Distributed Generation (DG) Pada Jaringan Distribusi Sistem Radial Menggunakan GA (Genetic Algoritm) Di Penyulang Watu Ulo Jember. Jember. Universitas Jember.

[2] Zad, B. Bakhshideh. 2015. Optimal Reactive Power Control Of Dgs For Voltage Regulation Of MV Distribution Systems Using Sensitivity Analysis Method And PSO Algorithm.
[3] Mohammad H. Moradi. 2014. An Efficient Hybrid Method For Solving The Optimal Sitting And Sizing Problem Of DG And Shunt Capacitor Banks Simultaneously Based On Imperialist Competitive Algorithm And Genetic Algorithm. Jurnal Volume 101-111. 